\title{
The Analysis of Wastewater Treatment System Efficiencies in Kenya: A Review Paper
}

\author{
Flory Kilingo*, Zulu Bernard**, Chen Hong -bin***+

\begin{abstract}
*UNEP-TONGJI Institute of Environmental Sciences and Sustainable Development (IESD) Tongji University, Shanghai, China. 200092. florymkangombe@gmail.com

**UNEP-TONGJI Institute of Environmental Sciences and Sustainable Development (IESD) Tongji University, Shanghai, China. 200092. Email: manbentry@yahoo.com

***The State Key Laboratory of Pollution Control and Resource Reuse, School of Environmental Sciences and
\end{abstract} \\ Engineering, Tongji University, Shanghai, China. 200092. Tel: 0086-21-65984569, Email: bhctxc@tongji.edu.cn
}

DOI: 10.29322/IJSRP.11.05.2021.p11322

http://dx.doi.org/10.29322/IJSRP.11.05.2021.p11322

\begin{abstract}
This study review focused on indicating wastewater treatment technologies used in Kenya and determine the most feasible and effective treatment method that can be applied in slum areas. This systematic literature review showed that the most commonly used treatment method in Kenya is the use of single or combined constructed wetland, stabilization ponds coupled with constructed wetland, stabilization pond with aerated lagoons, and also conventional wastewater treatment systems. However, the conventional method is costly and requires high implementation, maintenance and operation. Yet, most of the final effluents of the treatment system do not meet the National Environmental Management Authority (NEMA) standards hence posing a threat to the environment and human life. Found that most of the wastewater treatment plants were not effective in removing the nutrients (phosphorus and nitrogen) to the required standards. Ruai and Kariobangi treatment plants had a removal efficiency of pollutants at an average level of $82 \%$ and $48 \%, 71 \%$ and $51 \%, 72 \%$ and $68 \%,-7 \%$ and $15 \%$ for $\mathrm{BOD}, \mathrm{COD}, \mathrm{TSS}$, and $\mathrm{NO}_{3}{ }^{-}$respectively, and in Ruai and Kariobangi treatment plants respectively. While for waste stabilization pond (WSP) coupled with HF-CW at Jomo Kenyatta University of Agriculture and Technology (JKUAT) campus, $91 \%, 76 \%, 91 \%, 50 \%, 21 \%$ for $\mathrm{BOD}, \mathrm{COD}, \mathrm{TSS}, \mathrm{NH}_{4}-\mathrm{N}$, and T-P respectively and removal efficiencies obtained from a game resort constructed wetland and a hybrid wetland with the horizontal flow and free water surface, 78.5\% BOD, 86\% COD, 75\% TSS and $41 \%$ NH4-N, 21.4\% T-P, 96.2\% BOD, 84.5\% TSS, 97.6\% COD, 99.9\% E. coli and faecal coliform respectively. Generally, constructed wetland coupled with other methods had high pollutant removal compared to other methods. Therefore, this study reviewed the efficiency and feasibility of wastewater treatment methods used in Kenya and hence suggests an affordable treatment system to be used in the slum regions to curb the water scarcity challenge. Low operational cost and implementation, maintenance and simplified operation, and high-quality end effluents favor constructed wetland suitable for use in slum areas and developing countries in general for treating domestic wastewater. For the residents to have access to sufficient and sustainable sanitation, as well as clean water for irrigation and domestic use, attributable to constructed wetland systems.
\end{abstract}

Index Terms- Slums, Wastewater treatment, Conventional wastewater systems, constructed wetland, Water quality standards

\section{INTRODUCTION}

$\mathrm{W}$ ater shortage is a big global problem that has serious consequences for the environment and human health, of which the situation is expected to worsen in the coming years (Wakhungu, 2019; Zhang et al., 2015). Over one-tenth that is 2.5 billion people worldwide rely on the low-quality drinking water sources (Nadir et al., 2020; Organization, 2008), and of which about $42 \%$ of the sub-Saharan regions in Africa have inadequate safe drinking water and $47 \%$ in the globe will face water shortage challenge by 2030 (Mbui et al., 2016). Moreover, in the regions of arid and semi-arid, water-scarce has been experiential to rise to a higher level (Ndunda et al., 2013) also water supply-demand is said to exceed by $40 \%$ global and 50\% in the developing countries (Chellaney, 2013; Wakhungu, 2019).

Different cities in developing nations are facing a high challenge in the construction and management of wastewater treatment services, as being the least infrastructure advancement (Zhang et al., 2015). This has contributed to the use of the little freshwater available for irrigation, domestic use, in industries, and among other uses. The global water shortage and most importantly in developing 
countries for example in Africa is due to industrialization, urbanization, and high population growth which has led to a decrease in water accessibility per capita (Mulimi et al., 2020). Moreover, the lack of development of artificial storage capacity, reduction of natural storage capacity, fast-growing demand for water safety for multi-sectoral uses, and an annual sustainable freshwater resource per capita are also insufficient (Mulimi et al., 2020; Ngigi et al., 2006). The water issue is accelerated by the unsafe solid waste dumping from human settlements, agricultural and industrial activities (Dhote et al., 2012; Seow et al., 2016). Besides, about 80\% of wastewater worldwide is discharged directly to water bodies (Kalavrouziotis et al., 2016; Kinuthia et al., 2020) because of improper sanitation facilities such as blockage of wastewater channels causing water pollution (Kinuthia et al., 2020; Nansubuga et al., 2016), which in turn causes eutrophication of surface waters (Nadir et al., 2020).

Kenya among other countries experience a water crisis and it has been projected that by 2025 the drinking water availability will lower from $548 \mathrm{~m}^{3} /$ capita/decade to $250 \mathrm{~m}^{3} /$ capita/decade (Ndunda, 2014). This has led to the use of wastewater for various purposes such as food crops irrigation in the farms. The wastewater is directly discharged to open sewer lines increasing the health risks to residences such as water-borne diseases (Akullian et al., 2015; Nadir et al., 2020). Furthermore, high sewerage coverage particularly in developing nations has increased the cases of infectious diseases related to poor sanitation. Urban regions in Kenya such as, Kisumu covers $13 \%$, Mombasa 4\%, Nairobi $28 \%$ which gives the nation a total sewerage coverage of 17\% (K'oreje et al., 2016). Above all, improvements in the sanitation and management of sewage treatment facilities are the better option for acquiring quality water to minimize the use of the wastewater for irrigation without treatment in the low-income regions and for other domestic uses (Ndunda et al., 2013).

Nairobi is Kenya's capital city and is found in the southern central area (Mathews, 2019). It is a densely populated city in the East of Africa (Adhiambo, 2014) and has a population of 4.4 million people (KNBS, 2019) and an area of about $700 \mathrm{Km}^{2}$ (Alukwe, 2015). The country faces a great challenge, that is, most of the industries, agricultural run-off, and municipal wastewater are discharged into the environment leading to a high content of chemical and biological oxygen demand, and turbidity (Kinuthia et al., 2020; Odhiambo et al., 2016), and water bodies without undergoing treatment, or even just undergoing only the first stage of treatment (Abdel-Raouf et al., 2012). Moreover, most of the running sewers discharge directly to Nairobi, Mathare, and Ngong rivers causing high pollution of the water, threatening life such as human health, environment, and aquatic. Safety of the water from rivers is essential since is the source for domestic use especially in drinking water and other household uses in addition to agricultural purposes. A current study by Mulimi et al., (2020) indicated that a key way of ensuring freshwater is available to most of the countries worldwide is by reusing, reclamation, and recycling the wastewater. Similarly, wastewater treatment is the major solution to the water crisis worldwide and most importantly in African countries such as Kenya's densely populated towns for example the Nairobi city. In addition to that, effective wastewater treatment also ensures that the water allowed in the environment is safe from pollution. Together with the creation of public awareness for solid waste handling and sustainable wastewater management as the key subject in solving water-scarce in the region. This paper reviews efficiency of wastewater treatment technologies used in Kenya and determine the most feasible and effective treatment method that can be applied in slum areas such as Nairobi's Kibera slum.

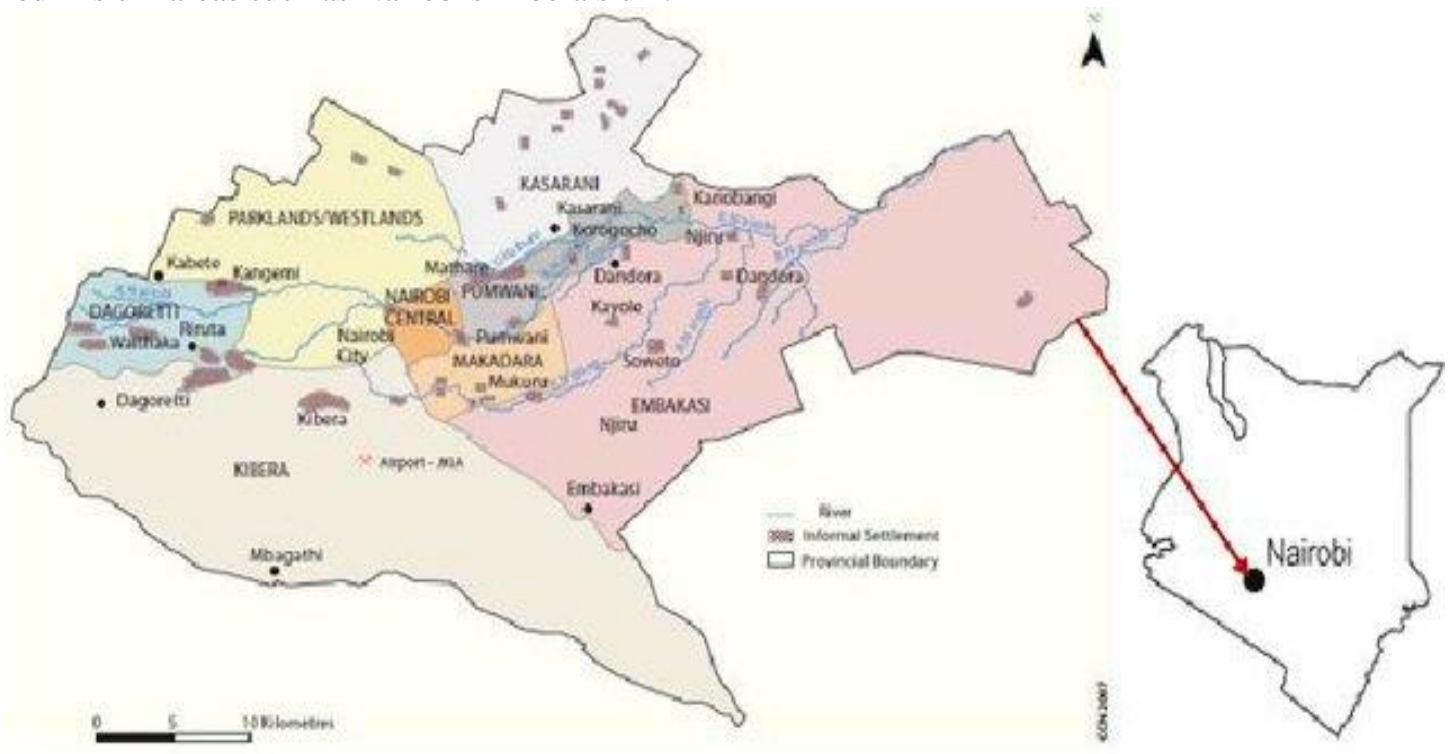

Figure 1: Area of Study- Nairobi City watershed and Boundary. Source: (Alukwe, 2015)

\subsection{Wastewater Treatment Processes used in Kenya}

The initial stages in wastewater treatment are the assembly of structures and the use of gravel tanks to eliminate the remaining waste which is most likely to interrupt the flow and subsequently stop the gears used in the next wastewater purification process. 


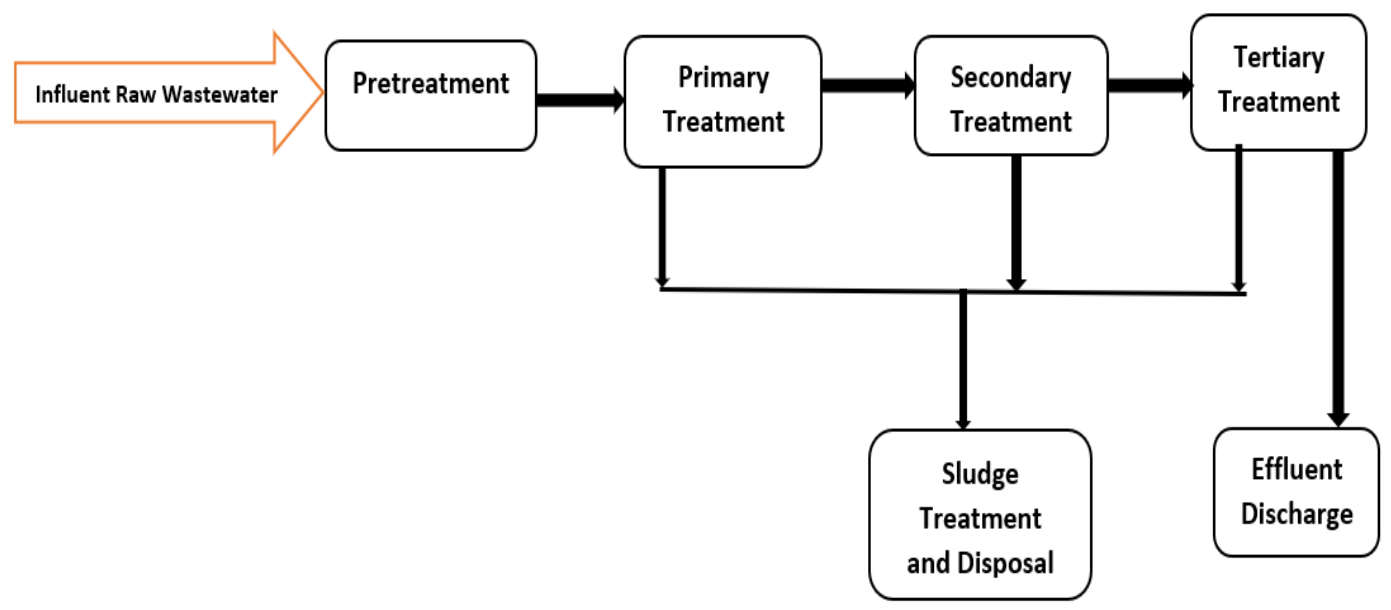

Figure 2: The commonly used processes for conventional wastewater treatment systems. Source: (Mwaka, 2019)

\subsubsection{Primary Treatment}

The primary treatment stage entails physical processes which involve screening, removal of grit material then by sedimentation process aimed at separating elimination of oil \& fatty acids, settleable, suspended, and solids that float like paper bags and related plastics (Miruka, 2016). However, the BOD and nutrients (phosphorus and nitrogen) are also removed at a low rate in the first stage of treatment.

\subsubsection{Secondary Treatment}

Organic nitrogen and biodegradable organic matter are removed and converted to water, carbon (IV) oxide, and nitrates through aerobic and or anaerobic microbial processes (Miruka, 2016). Moreover, the secondary treatment processes mainly employed are activated sludge, rotating bio-discs, constructed wetland, waste stabilization ponds, aquaculture, and trickling filters.

\subsubsection{Tertiary Treatment}

The stage mainly helps in the removal of nutrients, total nitrogen comprising of organic nitrogen and ammonium nitrogen, total phosphorus including particulate and soluble phosphorus distributed from the secondary effluent, TSS and $\mathrm{BOD}_{5}$. Besides, it is designed to help control eutrophication at the surface of waters and some re-use systems for example in the constructed wetlands, aquaculture, chemical precipitation, denitrification and nitrification, disinfection among others (Miruka, 2016).

The direct release of municipal wastewaters poses threats to the public health and ecosystem, leading to eutrophication and the outbreak of water-borne illnesses (Angassa et al., 2018). Besides, these challenges are observed to occur in areas with inadequate wastewater treatment plants and sanitation, industrialization, urbanization, and rapid population growth. However, there are different categories of wastewater technologies that have been developed, but they are costly in maintenance and operation, leading to low pollutants removal efficiency. Moreover, due to the availability of many options and standards, the most feasible methods for domestic wastewater treatment technology are usually unknown and difficult to determine. For example, investment cost, energy use, and efficiency of the methods in the removal of the pollutants are incorporated to determine which process is more reliable (Molinos-Senante et al., 2015). In addition to that, it is necessary to develop reliable approaches and treatment processes for domestic wastewater treatment which requires high removal efficiency i.e., a low-cost effluent quality, simple techniques, low investment cost, and operation in developing countries that experience water shortage. In Kenya, an efficient wastewater treatment method is needed to produce effluent that complies with environmental standards, but these protocols are rarely followed.

\subsection{Wastewater Situation in Kenya}

Rivers, dams, and lakes are the main water sources to Nairobi city residence and are highly polluted by direct discharge of wastewater from industries, households, and many other sectors without treatment (Alukwe, 2015; Kinuthia et al., 2020). Also, pollution of water bodies in the city is through high levels of pathogens and the microorganisms that are inflowing into water sources and the unsafe garbage collection in both the rural and urban regions (Seow et al., 2016).

Previous studies have shown that the poor urban regions, that is over 100,000 households use untreated wastewater for their cultivation purposes in which only about $50 \%$ of the generated wastewater in the city is directed in the wastewater treatment services (Benard et al., 2012; Mwangi, 2016). The Kibera region specifically being the biggest slum in the city depends mostly on the wastewater 
for farming due to inadequate water supply in the area, and much of the wastewater produced in the area is directly discharged into water bodies such as the nearby Nairobi and Ngong rivers due to lack of proper sewer lines. Additionally, farmers access the wastewater for their farms by blocking the sewer storage channels from the residential and allowing the wastewater to flow through the farming areas (Mwangi, 2016). However, wastewater is viewed as a resource that provides a solution to their everyday challenges (WWAP, 2017). Nairobi city encounters great challenges such as waste collection, inadequate sewage disposal points, and inadequate sanitation facilities which are mainly caused by the increase in population due to rural-urban migration in the country (Alukwe, 2015), thus, leading to the deterioration of the environment. The majority of sewage plants today use the outdated system and have insufficient handling capacity, resulting in large amounts of untreated wastewater or sewage that hasn't been properly treated is being discharged into the environment. The raw or partly treated wastewater is discharged directly to the water sources affecting the fauna and flora (Connor et al., 2017; Mwangi et al., 2020). Therefore, the solution to the provision of enough domestic and agricultural water uses and a healthy environment to residents in the city is by employing proper disposal and treating the wastewater (Malik et al., 2015).

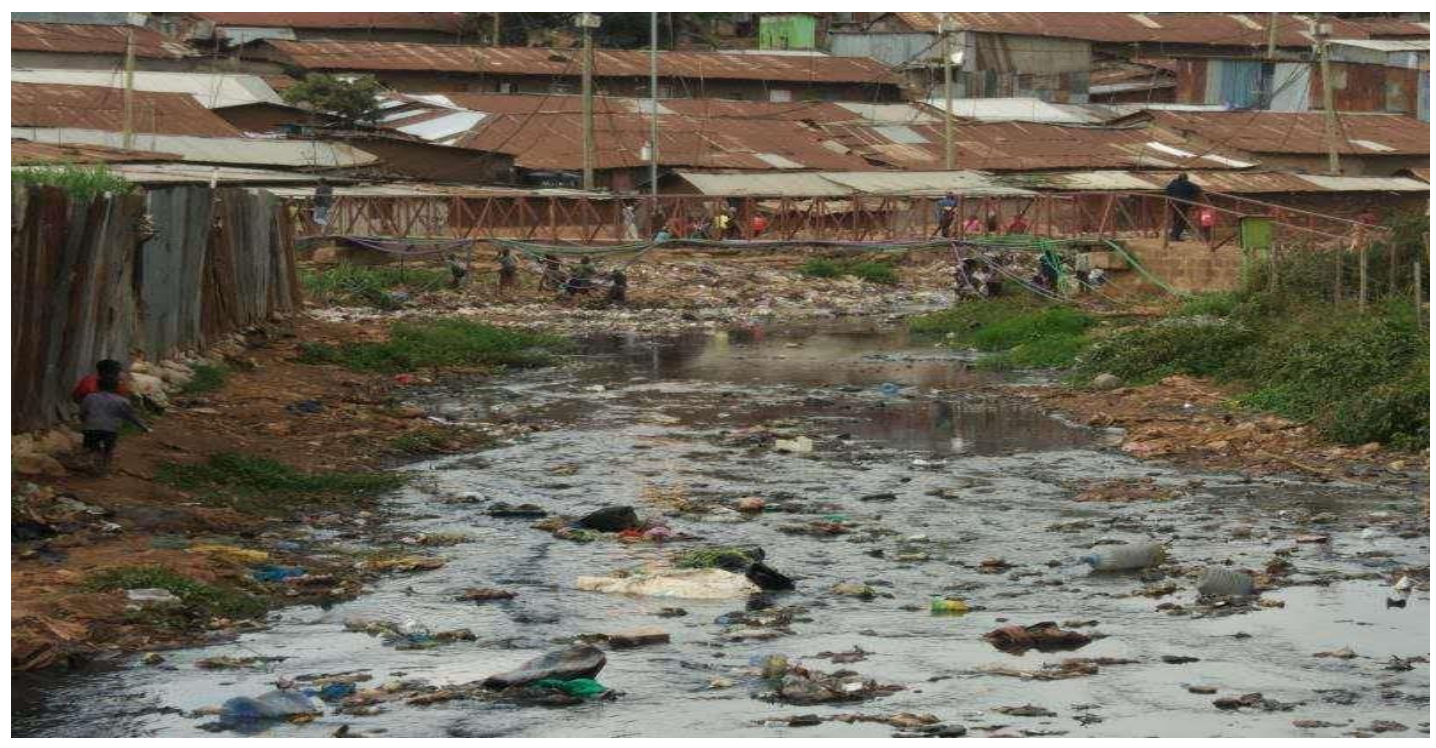

Figure 3: Domestic wastewater open sewer lines in Soweto East, Kibera slum

\subsection{Wastewater Treatment in Kenya}

Dealing with wastewater situation is a menace that has overwhelmed developing countries affecting their surface waters as the discharge of raw wastewater has caused the environment to deteriorate (Pavithra \& Hina, 2016; Wanjohi et al., 2020). Treating the wastewater allows household and industrial wastewater to be discharged without danger to the public health or degradation of the natural world. Therefore, a study on the quality of treated wastewater for reuse by Maina et al., (2020), pointed out that there are quite a few wastewater treatment systems in Kenya that are managed by Nairobi City Water and Sewerage Company (NCWSC) that treats different kinds of wastewater. And also, according to data from Kenya's sewage treatment database, (Bundi et al., 2018), there are 49 sewage treatment systems in total, 27 of which use stabilization technology (Table 1). Above all, the wastewater management of Kenya has not effectively been addressed by the government, political and social leaders (Makopondo et al., 2020; Wanjohi et al., 2020), and to curb water scarcity is by ensuring good monitoring of the treatment plant and re-use of the treated wastewater to increase water accessibility to the residence in the country.

Table 1: Sewage treatment systems in Kenya

\begin{tabular}{|c|c|c|c|}
\hline Technology & $\begin{array}{l}\text { Number of public } \\
\text { country }\end{array}$ & plants in the & Comments \\
\hline Constructed wetlands & 10 & & Majorly used in the urban center \\
\hline Oxidation ditch & 3 & & Used in a relatively small urban center \\
\hline Conventional (Activated Sludge) & 6 & & In bad conditions \\
\hline Stabilization Ponds & 27 & & Publicly operated systems \\
\hline Aerated lagoons & 3 & & \\
\hline Total & 49 & & \\
\hline
\end{tabular}




\subsubsection{Conventional in comparison to stabilization pond for wastewater treatment method}

The treatment systems comprise numerous processes such as chemical, biological and physical, which help in pollutant removal in the wastewater such as high nutrients concentration, organic content, and solid particles. A study by Joel et al., (2018) argued that the conventional wastewater treatment systems, in most cases, while aiming at reducing pollution load on the ecosystem results in effluents with high bacterial load, biological oxygen demand, phosphorus, and nitrogen posing a threat to the receiving environment. Moreover, a study by Mochu et al., (2016) noted that conventional treatment facilities are mainly used in Kenya but they are few and not in good condition because of the high financial cost of operating and maintenance.

The Kariobangi treatment plant is a conventional plant-based on biological aerated filters for wastewater treatment and a system with a capacity of $32,000 \mathrm{~m}^{3} /$ day. The filtering technology is mainly used for the purification of water. Secondly, there are the Dandora estate sewage treatment works (DESTW) in Ruai Kenya which is Africa's second-largest wastewater treatment facility and the largest in Nairobi City. The Dandora stabilization ponds are a lagoon-based plant with artificial aeration to facilitate biological oxidation of wastewater and are mainly used to treat industrial and domestic sewage together (Wang et al., 2014), to reduce the concentrations of the pollutant load from the industries. Additionally, the wastewater treatment plant (WWTP) treats about $80,000 \mathrm{~m}^{3} /$ day which is about $80 \%$ of the produced wastewater in the city (Song'oro et al., 2019), with a BOD 5 removal of $91 \%$ according to Lukhabi, (2018). Furthermore, its daily maximum volume is $120,000 \mathrm{~m}^{3}$ /day (Opijah et al., 2007).

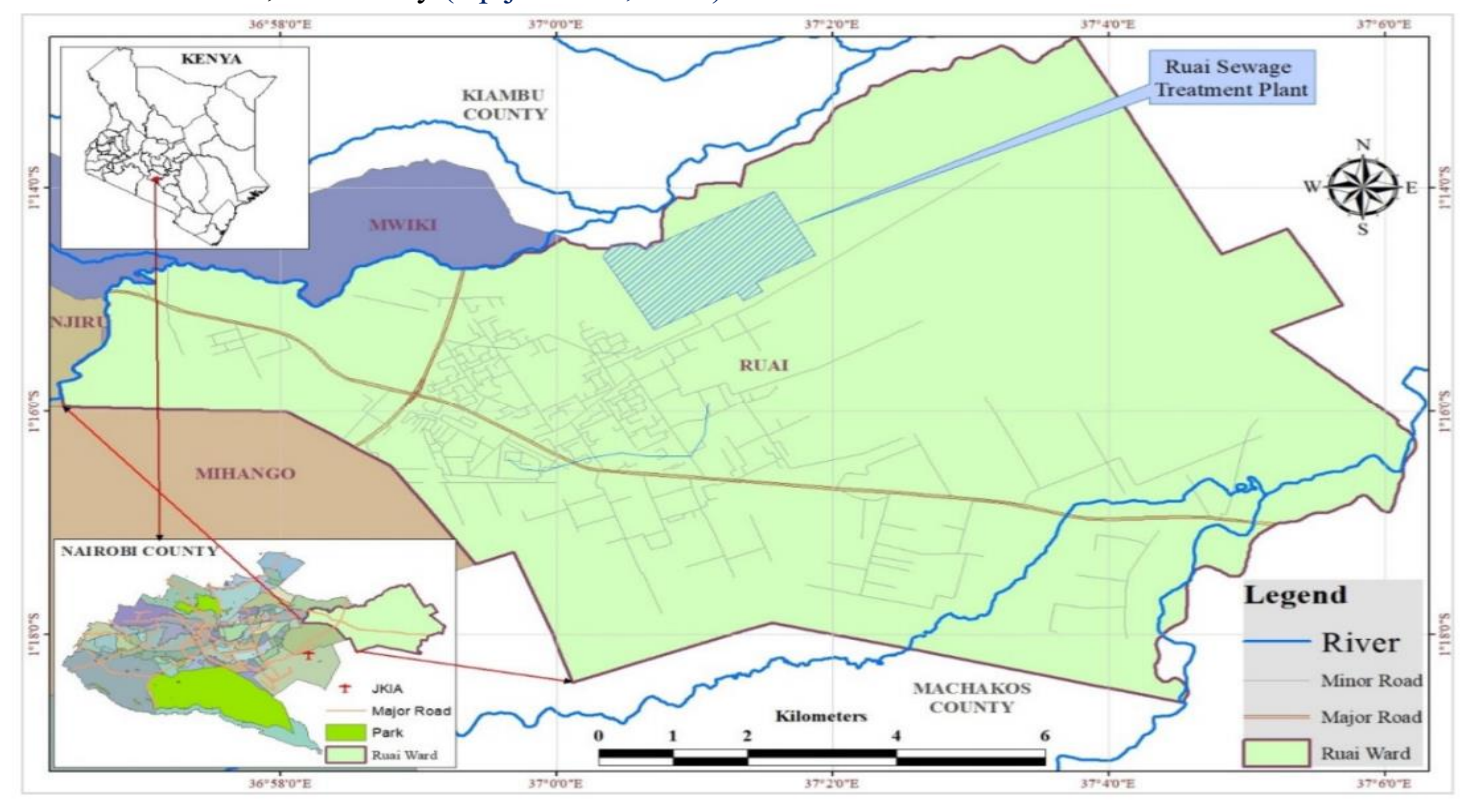

Figure 4: Ruai/Dandora wastewater treatment plant in Kenya. Source: (Maina et al., 2020) 


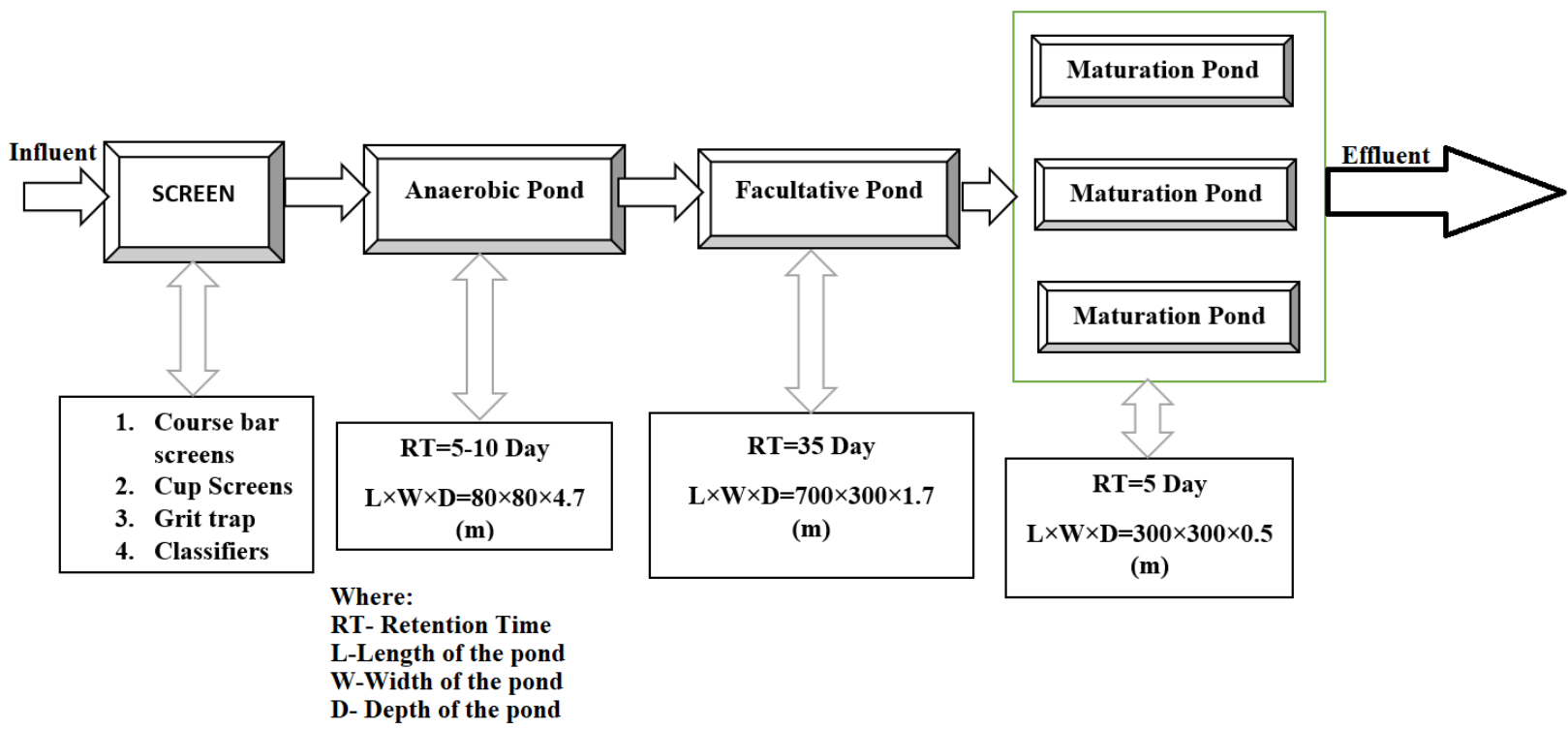

Figure 5: Dandora/Ruai wastewater treatment plant schematic flowchart process in Nairobi, Kenya. Source:(Wang et al., 2014)

The results for the Ruai and Kariobangi WWTP showed inefficient treatment of the wastewater providing effluent above the allowable limits for the country (Maina et al., 2020). Overall, the results showed that TSS $131 \mathrm{mg} / 1 \mathrm{and} 71 \mathrm{mg} / 1$, COD $291 \mathrm{mg} / 1 \mathrm{and}$ $316.3 \mathrm{mg} / \mathrm{l}$, and $\mathrm{BOD}_{5} 70 \mathrm{mg} / \mathrm{l}$ and $164 \mathrm{mg} / \mathrm{l}$ as the effluents levels of the Ruai and Kariobangi sewage treatment plants respectively are much higher than the national standard for discharge to water sources and land of TSS (30mg/l), COD (50mg/l) and BOD (30mg/l). Whereas only the nitrate effluent $(13.5 \mathrm{mg} / \mathrm{l})$ of the Ruai treatment system exceeded the national standards of $10 \mathrm{mg} / \mathrm{l}$. Moreover, other studies also observed $\mathrm{BOD}_{5}, \mathrm{COD}$, TSS, and phosphorus effluent concentration of the treated wastewater did not meet the required standard for Kenya's environmental pollution control and reuse purposes (Sewe, 2013; Shikuku et al., 2017).

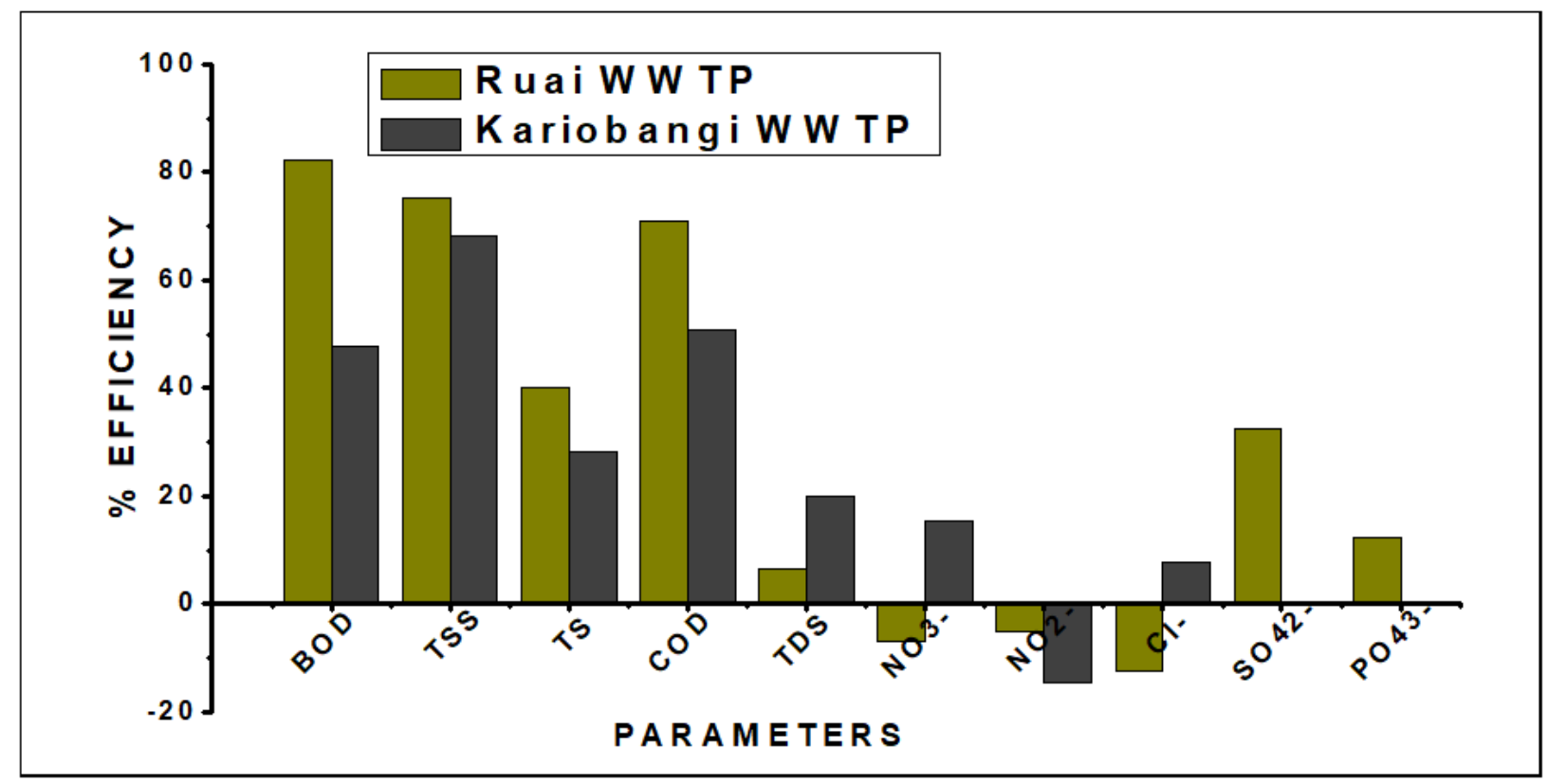

Figure 6: Efficiencies of Ruai and Kariobangi wastewater treatment plants in pollutants removal

A study by Joel et al., (2018) experimented on the performance of the Boundary Sewage Treatment Plant in Eldoret a conventional wastewater treatment system that treats both domestic and industrial wastewater. The effluent concentration for biological oxygen demand, TDS, pH, COD, and TSS, since the Kenya National Environmental Management Authority (NEMA), did not provide the guidelines of some of the parameters to use the treated wastewater for irrigation, they were compared to irrigation guidelines from various countries that irrigate with treated wastewater (Table 2). Irrigation of wastewater, whether treated or not, is illegal in Kenya, but it is exercised illegally by poor urban residents. 
Table 2: The treatment system's final effluent compared to the recommended guidelines for using treated water in irrigation. Source (Joel et al., 2018)

\begin{tabular}{ccc}
\hline Parameter & Mean \pm SE & Recommended Standards \\
\hline TDS $(\mathrm{mg} / \mathrm{L})$ & $722.7 \pm 9.21$ & $\leq 1200$ (NEMA) \\
COD $(\mathrm{mg} / \mathrm{L})$ & $169.0 \pm 0$ & $\leq 100$ (Jordan) \\
BOD $(\mathrm{mg} / \mathrm{L})$ & $82.67 \pm 4.33$ & $\leq 30$ (Washington) \\
pH & $8.05 \pm 0.03$ & $6.5-8.5$ (NEMA) \\
TSS (mg/L) & $90.00 \pm 0$ & $\leq 30$ (Washington) \\
\hline
\end{tabular}

\subsubsection{Waste Stabilization Ponds}

\subsubsection{Description of Wastewater Stabilization Ponds (WSP)}

Wastewater stabilization ponds are mainly used for secondary treatment of different kinds of wastewater which is approximated to about $90 \%$ of the wastewater generated in Kenya (Omosa et al., 2012). Additionally, the systems are prone to overloading due to a high rate of a growing population in the country and also, they are poorly operated and maintained because of high cost. Furthermore, one of the treatment systems treating domestic wastewater is installed in JKUAT in Juja town, Kenya with a design volume of 10, 000 people, and is currently experiencing an overload of about 20,000 people and with a flow rate of $1400 \mathrm{~m}^{3} /$ day. Equally important, the wastewater treatment system comprises a maturation pond, 2 secondary facultative ponds, and 2 primary facultative ponds after which the treated water is being drained to the nearby water sources such as the river Ndarugu (Muriuki et al., 2020). The discharged of partly treated wastewater particularly from industries disturbs the environment and all its resources and also negatively affects the aquatic life when the wastewater with a high concentration of nutrients, BOD, TSS, COD, TDS, and turbidity as the main determinants of the water quality are allowed into water sources (Ramin et al., 2021).

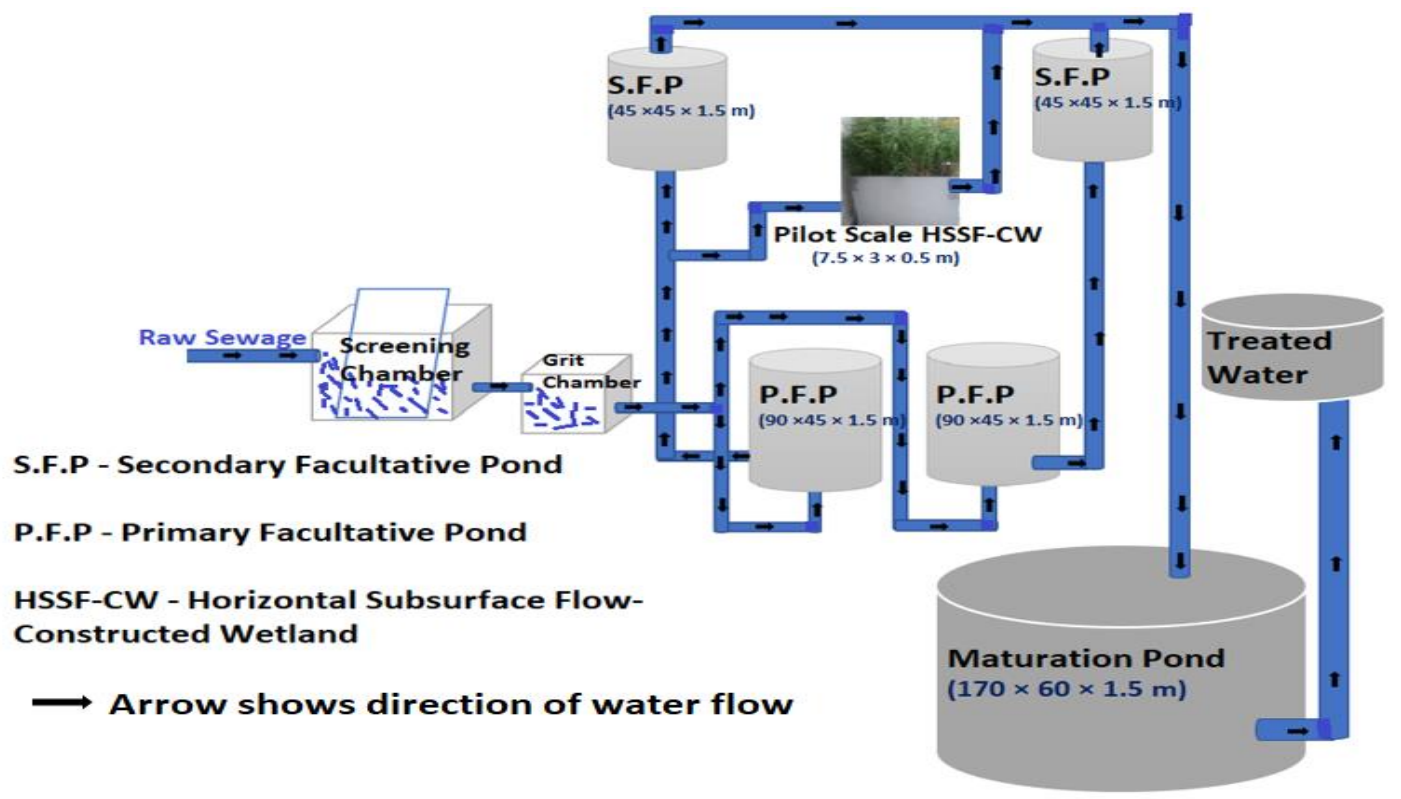

Figure 7: JKUAT Sewage Treatment Works, a schematic layout of a pilot-scale HF-CW and waste stabilization ponds. Source:

(Mburu et al., 2013)

\subsubsection{Performance analysis of WSP in pollutants removal in wastewater combined with HF-CW}

A research study by Mburu et al., (2013), assessed the performance of a wastewater stabilization pond (WSP) coupled with an HF-CW planted with macrophyte Cyperus papyrus that receives the primary effluent from the treatment system's outflow of the primary 
facultative ponds treating campus domestic wastewater from Jomo Kenyatta University of Agriculture and Technology (JKUAT). Additionally, the wetland system has a mean flow rate of $3 \mathrm{~m}^{3} /$ day and HRT of 1.5 days and was applied for the secondary treatment processes. The WSP reduced TSS and BOD to more than 90\%, COD 76\%, ammonium nitrogen 50\%, and T-P 21\%. Comparatively, the HF-CW reduced TSS, BOD, and COD to more than $84 \%$ from the influent of the treatment system, however, the T-P removed to $26 \%$ and $\mathrm{NH}_{4}-\mathrm{N}$ to $8 \%$. Whereas effluent of the PFP was the influent of the HF-CW, thus the wetland registered removal for COD (73\%), BOD (61\%), T-P (25\%), TSS (66\%) and there was no removal for $\mathrm{NH}_{4}-\mathrm{N}$ observed. The poor removal efficiency and a high $\mathrm{NH}_{4}-\mathrm{N}$ concentration observed in the HF-CW effluent in comparison to WSP effluent is contributed to the system's subsurface flow environment's insufficient re-oxygenation capability. Except for $\mathrm{NH}_{4}-\mathrm{N}$ and T-P, the WSP effluent results for all other parameters are within the NEMA standards discharge guidelines. The performance effluent of the HF-CWs also surpassed the $\mathrm{NH}_{4}-\mathrm{N}$ and T-P discharge limit values for discharge to the land and surface water. Above all, the wastewater stabilization ponds (WSPs) and HF-CW have been reported to have limited nutrient removal.

Table 3: The removal efficiencies and the effluent quality of the water of the treatment systems in the JKUAT campus

\begin{tabular}{|c|c|c|c|c|c|c|c|c|c|c|}
\hline \multicolumn{11}{|l|}{ System } \\
\hline & $\begin{array}{l}\text { BOD } \\
(\mathrm{mg} / \mathrm{l})\end{array}$ & $\%$ & $\begin{array}{l}\text { COD } \\
(\mathrm{mg} / \mathrm{l})\end{array}$ & $\%$ & $\begin{array}{c}\mathrm{NH} 4-\mathrm{N} \\
(\mathrm{mg} / \mathrm{l})\end{array}$ & $\%$ & $\begin{array}{l}\mathrm{TP} \\
(\mathrm{mg} / \mathrm{l})\end{array}$ & $\%$ & $\begin{array}{c}\mathrm{TSS} \\
(\mathrm{mg} / \mathrm{l})\end{array}$ & $\%$ \\
\hline Influent & $232 \pm 133.3$ & & $424 \pm 277.4$ & & $39 \pm 13.6$ & & $4 \pm 0.9$ & & $118 \pm 87.6$ & \\
\hline PFP & $74 \pm 17.7$ & 68 & $216 \pm 110.9$ & 49 & $34 \pm 10.6$ & 14 & $4 \pm 0.7$ & 5 & $56 \pm 14.9$ & 52 \\
\hline SFP & $48 \pm 14.6$ & 79 & $160 \pm 77.3$ & 62 & $35 \pm 13.8$ & 11 & $3 \pm 0.6$ & 21 & $39 \pm 22.9$ & 67 \\
\hline MP & $20 \pm 16$ & 91 & $100 \pm 37$ & 76 & $17 \pm 11$ & 50 & $3 \pm 0.6$ & 21 & $10 \pm 20$ & 91 \\
\hline $\begin{array}{l}\mathrm{HF}-\mathrm{CW} \\
\text { (planted) }\end{array}$ & $29 \pm 9$ & 87 & $58 \pm 17.4$ & 86 & $36 \pm 8$ & 8 & $3 \pm 0.3$ & 26 & $19 \pm 8.7$ & 84 \\
\hline $\begin{array}{l}\text { NEMA } \\
\text { Standards }\end{array}$ & 40 & & 120 & & 1 & & 1 & & 35 & \\
\hline
\end{tabular}

PFP (Primary Facultative Ponds), SFP (Secondary Facultative Ponds), MP (Maturation Ponds) and HF-CW (Horizontal flow constructed wetland)

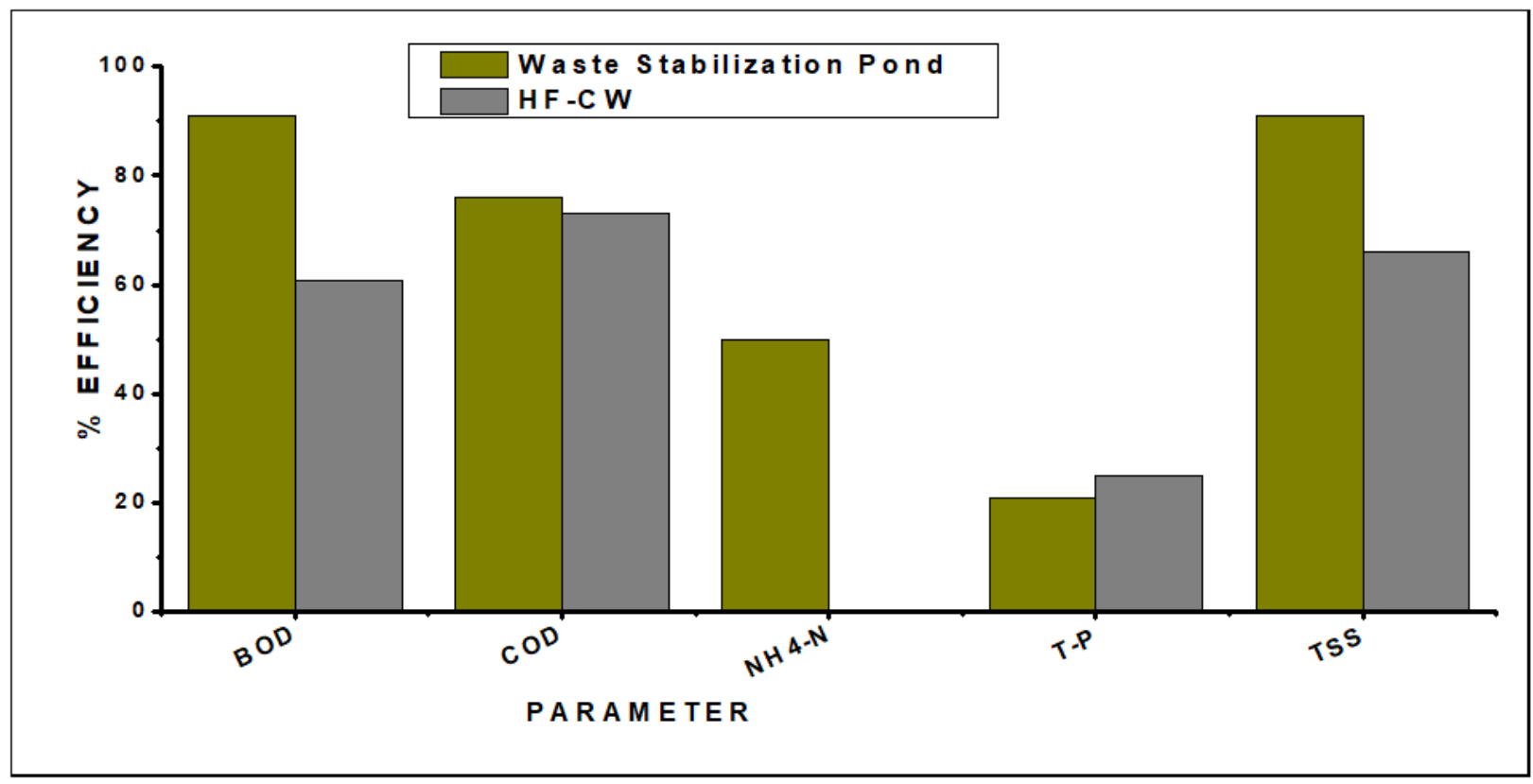

Figure 8: The removal efficiencies of the WSP compared to the HF-CW in treating domestic wastewater in JKUAT

Another study by K'oreje et al., (2018) examined the performance of wastewater stabilization ponds of organic load mean range removal of $75-90 \%$, and the effluent $\mathrm{COD}$ and $\mathrm{BOD}_{5}$ did not meet the requirements for effluent discharged into the environment in East Africa at a concentration of $30 \mathrm{mg} / \mathrm{l}$ and $60 \mathrm{mg} / 1$ respectively. However, elevated photosynthetic activity of algae in the maturation ponds and large solar irradiation is attributable to higher values of both parameters at the effluent. Research by Nyakang'o et al., (1999), reported the efficacy of landscaping designed HF-CW combined with a series of 3 pond system in treating domestic wastewater and total nitrogen (TN) 90\%, TSS 85\%, orthophosphate $88 \%$, $\mathrm{BOD}_{5} 98 \%, \mathrm{NH}_{4}-\mathrm{N} 92 \%$, and COD $96 \%$ were achieved. 


\subsubsection{Constructed wetland (CW) system}

Constructed wetlands treatment technologies in Kenya are used in handling different wastewater in different regions (Mwaka, 2019). They are the most economical wastewater treatment methods globally and most importantly in developing countries for the better quality of the treated water which can be reused (Wang et al., 2017). Kenya adopted the use of these facilities to treat domestic wastewater mainly from restaurants using the subsurface and surface flow systems (Nzengy'a et al., 2001), as the first Splash wetland constructed in Nairobi city, Kenya.

\subsubsection{The performance of $\mathrm{CW}$ wastewater treatment methods}

A study by Makopondo et al., (2020) identified the efficacy, benefits, and disadvantages of using the wetland systems in wastewater treatment from Kenya's resorts and game lodges. The observation made for the system by the study is that they are effective in the elimination of the pollutants from the wastewater to reusable in landscaping, easy to start up, cost-effective in operation and maintenance, low in energy consumption, and handles adjustable flows. The research study by Makopondo et al., (2020), assessed the constructed wetland's effectiveness in contaminants removal from wastewater generated from game resorts and Lodges in Kenya, and an average removal of $86 \%$ COD, $75 \%$ TSS, and $78.5 \%$ BOD was stated.

In Kenya, a hybrid wetland at full scale comprising HF and free water surface (FWS) wetlands for residential treatment of wastewater and flower farm wastewater was conducted (Kelvin et al., 2011). The system presented a removal efficiency of 96.2\% BOD, 84.5\% TSS, $97.6 \%$ COD, $41 \%$ ammonia, $21.4 \%$ T-P, and $99.99 \%$ decrease in both the E. coli and fecal coliforms. Heavy metal removal by the wetland system was also assessed with the removal of nickel (Ni) $92 \%$, chromium $(\mathrm{Cr}) 60 \%$, lead $(\mathrm{Pb}) 89.9 \%$, and zinc $(\mathrm{Zn}) 96 \%$. In a similar type of construction, a study reported $94.5 \%$ COD, 97.6\% TSS, and 96.1\% BOD 5 efficiencies for a splash restaurant wastewater treatment system in Nairobi (Belachew, 2018). The effluents were within the set standards by the NEMA standards of Kenya and the World Health Organization (WHO).

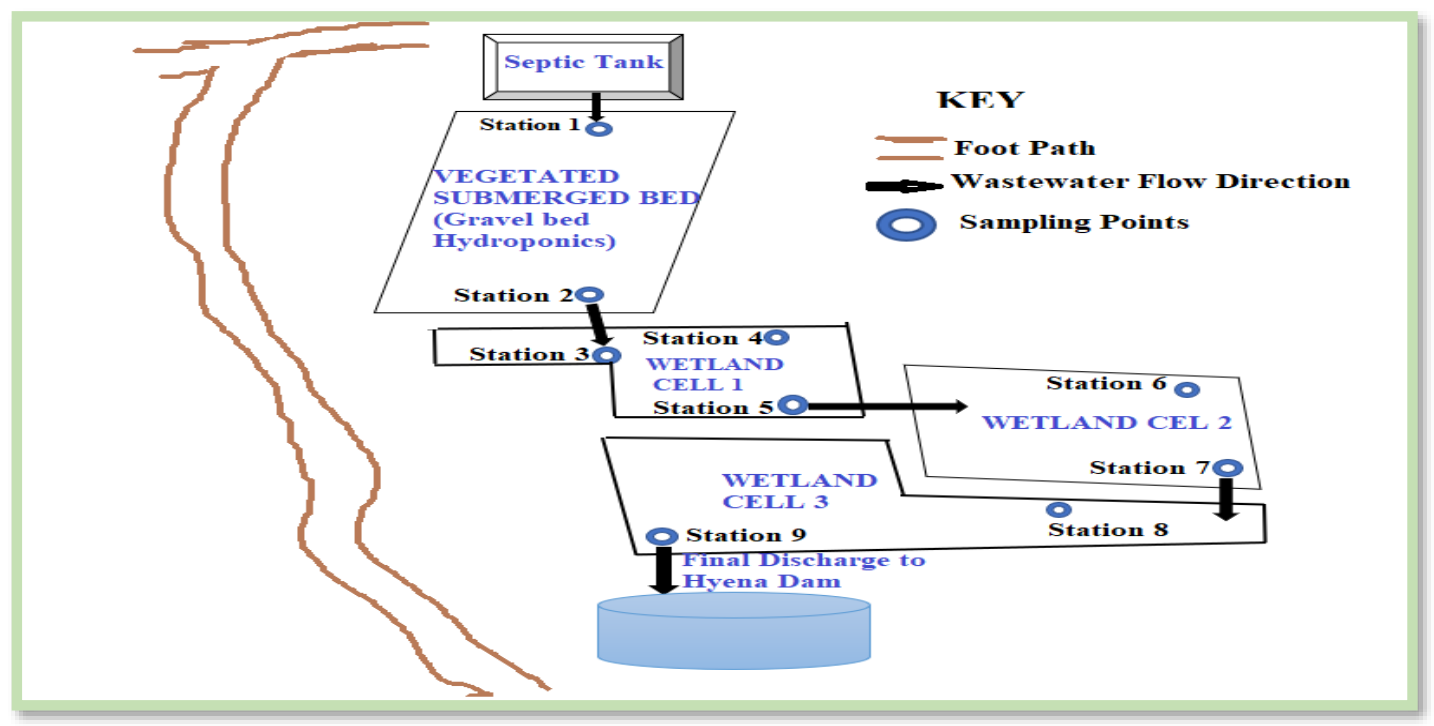

Figure 9: Schematic diagram of a splash restaurant constructed wetland treatment

\subsection{Other reasons for wastewater treatment system inefficiency}

According to a recent study by Wanjohi et al., (2020), reported that it is difficult to meet national standards for the effluent from the wastewater treatment systems due to poor disinfection efficiency, insufficient funds for energy supply and sewage treatment, and sludge sedimentation. Consequently, high levels of $\mathrm{BOD}_{5}$ and $\mathrm{COD}$ concentration are because of high levels of organic contents in the wastewater, excess amount of sludge accumulation, and overfilling of the treatment plant. Furthermore, the inefficiency of these treatment plants such as the Kariobangi WWTP stems from insufficient service, poor design, operation and maintenance, and low sewer connection rates. As for the nitrates and ammonium nitrogen removal by the constructed wetland is by the denitrification and nitrification process sufficiently take place at temperatures between $20-25^{\circ} \mathrm{C}$ and $16.5-32^{\circ} \mathrm{C}$ respectively (Kumar et al., 2020). Temperatures between 20-25 ${ }^{\circ} \mathrm{C}$ are essential for microbial activity and biological removal of nitrogen in the wastewater by wetland system (Lee et al., 2009). Furthermore, at a temperature between 15 to $23^{\circ} \mathrm{C}$, the plants grow strong and help in the uptake of the nitrogen content in the wastewater. However, the system temperature was favorable for the nitrification and plant uptake for ammonia, phosphorus, and total phosphorus removal. Therefore, the low removal of the total phosphorus and ammonium nitrogen is attributed to the low retention time and higher loading rate of the wetland system. As a result, an alternative approach for pollutant removal in wastewater that is cost-effective, reliable, 
and successful should be considered. To substitute conventional treatment approaches, wetland systems in a combined state is a great investment because it uses the natural processes for wastewater treatment.

\section{CONCLUSION}

The poor quality of treated water effluent with a high concentration of BOD, TSS, phosphorus, lead, nitrate, and COD were above the defined regulatory discharge standards contributed by the insufficient and inefficient treatment system. Waste stabilization ponds and the single-operated constructed wetland were both inefficient in the removal of the nutrients. The waste stabilization pond's effluent yield at JKUAT for domestic wastewater treatment was within the set standards by NEMA Kenya. The horizontal flow constructed wetland recorded a negative removal efficiency for the ammonium nitrogen pollutant in the pretreated effluent from the primary facultative pond and the effluent quality was above the set limits. The constructed wetland has shown to be effective crosswise compared to other methods in treating wastewater efficiently when coupled with a better method. Additionally, they are a better option than the conventional treatment systems and waste stabilization ponds because they are easy to maintain and control the effluent quality production by effectively adjustable hydraulic loading rate, retention time, organic loading rate, and the flow rate of the system. Also, they are cost-effective, sustainable, and environmentally friendly, and the most economical and feasible wastewater treatment system in developing countries.

\section{RECOMMENDATION}

Owing to the nature of anaerobic, aerobic, and anoxic processes, the coupling of vertical flow and horizontal flow constructed wetlands can be applied for optimization of nitrogen and organic matter reduction. Therefore, they can be combined to support one another as a hybrid constructed wetland and produce a low polluted effluent. Consequently, the use of wetland can easily be applied in the slum regions for the treatment of wastewater discharged to the environment without proper sewer channels. Also, there should be improved maintenance and operation of the treatment plants through close monitoring to avoid producing effluent which does not meet the discharge standards to the environment. Regulations to be enforced to minimize the discharge of raw and or partially treated wastewater to water sources to avoid great damage to the environment, aquatic life, and human health. Also, more advanced wastewater treatment techniques to be developed as a treatment system for industrial and domestic wastewater to meet discharge standards.

\section{ACKNOWLEDGMENT}

We thank our supervisor, Prof. Chen Hongbin and our lab mates for all kinds of support. We also thank Mkala Mbandi Elijah for his comments and suggestions. All authors have read and agreed on the manuscript version to be published.

\section{REFERENCES}

[1] Abdel-Raouf, N., Al-Homaidan, A., \& Ibraheem, I. (2012). Microalgae and wastewater treatment. Saudi journal of biological sciences, 19(3), 257-275.

[2] Adhiambo, J. L. (2014). wastewater management: A case of reducing wastewater released into the environment in Mathare North, Nairobi county.

[3] Akullian, A., Ng'eno, E., Matheson, A. I., Cosmas, L., Macharia, D., Fields, B., . . Walson, J. L. (2015). Environmental transmission of typhoid fever in an urban slum. PLoS neglected tropical diseases, 9(12), e0004212.

[4] Alukwe, I. A. (2015). Modeling nitrogen and phosphorus fluxes in Nairobi City-Kenya. World Journal of Environmental Engineering,(3), 3, 67-81.

[5] Angassa, K., Leta, S., Mulat, W., Kloos, H., \& Meers, E. (2018). Organic matter and nutrient removal performance of horizontal subsurface flow constructed wetlands planted with Phragmites karka and Vetiveria zizanioide for treating municipal wastewater. Environmental Processes, 5(1), 115-130.

[6] Belachew, M. D. (2018). Performance evaluation of pilot-scale constructed wetlands for the treatment of domestic wastewater in Addis Ababa, Ethiopia.

[7] Benard, O., \& Omondi, G. (2012). Wastewater production, treatment, and use in Kenya. Paper presented at the Third regional workshop safe use of wastewater in agriculture, Johannesburg.

[8] Bundi, L. K., \& Njeru, C. W. (2018). Use of vegetative wastewater treatment systems for counties' effluent management in Kenya. Rwanda Journal of Engineering, Science, Technology and Environment, 1(1).

[9] Chellaney, B. (2013). Water, Peace, and War: Confronting the global water crisis: Rowman \& Littlefield.

[10] Connor, R., Renata, A., Ortigara, C., Koncagül, E., Uhlenbrook, S., Lamizana-Diallo, B. M., . . Sjödin, J. (2017). The United Nations world water development report 2017. Wastewater: The untapped resource. The United Nations World Water Development Report.

[11] Dhote, J., Ingole, S., \& Chavhan, A. (2012). Review on wastewater treatment technologies.International journal of science and Technology, 1, 1-10.

[12] Githuku, C. (2009). Assessment of the environmental risks of wastewater reuse in urban and peri-urban agriculture in Nairobi. MSc Thesis, JKUAT.

[13] Joel, C., Mwamburi, L. A., \& Kiprop, E. K. (2018). Use of slow sand filtration technique to improve wastewater effluent for crop irrigation. Microbiology Research, 9(1), 14-18.

[14] K'oreje, K., Vergeynst, L., Ombaka, D., De Wispelaere, P., Okoth, M., Van Langenhove, H., \& Demeestere, K. (2016). Occurrence patterns of pharmaceutical residues in wastewater, surface water and groundwater of Nairobi and Kisumu city, Kenya. Chemosphere, 149, 238-244.

[15] K'oreje, K. O., Kandie, F. J., Vergeynst, L., Abira, M. A., Van Langenhove, H., Okoth, M., \& Demeestere, K. (2018). Occurrence, fate and removal of pharmaceuticals, personal care products and pesticides in wastewater stabilization ponds and receiving rivers in the Nzoia Basin, Kenya. Science of The Total Environment, 637, 336-348.

[16] Kalavrouziotis, I. K., \& Koukoulakis, P. (2016). Wastewater and sludge reuse management in agriculture. EQA-International Journal of Environmental Quality, 20,1-13.

This publication is licensed under Creative Commons Attribution CC BY.

http://dx.doi.org/10.29322/IJSRP.11.05.2021.p11322

WWW.ijsrp.org 
[17] Kelvin, K., \& Tole, M. (2011). The efficacy of a tropical constructed wetland for treating wastewater during the dry season: the Kenyan experience. Water, Air, \& Soil Pollution, 215(1), 137-143.

[18] Kinuthia, G. K., Ngure, V., Beti, D., Lugalia, R., Wangila, A., \& Kamau, L. (2020). Levels of heavy metals in wastewater and soil samples from open drainage channels in Nairobi, Kenya: community health implication. Scientific Reports, 10(1), 1-13.

[19] KNBS. (2019). Population and house results. Kenya Bureau of Statistics KNBS, Kenya.

[20] Kumar, S., Pratap, B., Dubey, D., \& Dutta, V. (2020). Removal of nutrients from domestic wastewater using constructed wetlands: assessment of suitable environmental and operational conditions. Environmental Sustainability, 1-12.

[21] Lee, C. g., Fletcher, T. D., \& Sun, G. (2009). Nitrogen removal in constructed wetland systems. Engineering in Life Sciences, 9(1), 11-22.

[22] Lukhabi, D. K. (2018). Characterization of Egerton University wastewater stabilization ponds and assessment of substrate size efficiency in reduction of faecal pollutants in a constructed wetland mesocosm. Egerton University.

[23] Maina, G. I., Mwakumanya, M. A., Wamukota, A. W., \& Kilifi, K. (2020). Current Status in Quality of Treated Wastewater for Potential Reuse Scheme in Ruai, Nairobi County, Kenya.

[24] Makopondo, R. O., Rotich, L. K., \& Kamau, C. G. (2020). Potential Use and Challenges of Constructed Wetlands for Wastewater Treatment and Conservation in Game Lodges and Resorts in Kenya. The Scientific World Journal, 2020.

[25] Malik, O. A., Hsu, A., Johnson, L. A., \& de Sherbinin, A. (2015). A global indicator of wastewater treatment to inform the Sustainable Development Goals (SDGs). Environmental Science \& Policy, 48, 172-185.

[26] Mathews, O. N. (2019). Industrial discharge in Nairobi: An analysis of the regulatory environment, quality of discharge and media coverage.

[27] Mbui, D., Chebet, E., Kamau, G., \& Kibet, J. (2016). The state of water quality in Nairobi River, Kenya. Asian Journal of Research in Chemistry, 9(11), 579-586.

[28] Mburu, N., Tebitendwa, S. M., van Bruggen, J. J., Rousseau, D. P., \& Lens, P. N. (2013). Performance comparison and economics analysis of waste stabilization ponds and horizontal subsurface flow constructed wetlands treating domestic wastewater: A case study of the Juja sewage treatment works. Journal of environmental management, 128, 220-225.

[29] Miruka, A. (2016). The efficiency of Nairobi's Kariobangi Wastewater treatment plant: Pdf.

[30] Mochu, W., Munala, G., \& Njuguna, M. (2016). Domestic wastewater management in satellite towns around Nairobi city: A comparative study of Mlolongo and Ruiru in Kenya

[31] Molinos-Senante, M., Gómez, T., Caballero, R., Hernández-Sancho, F., \& Sala-Garrido, R. (2015). Assessment of wastewater treatment alternatives for small communities: An analytic network process approach. Science of the Total Environment, 532, 676-687.

[32] Mulimi, L. K., Home, P. G., Chacha, J. S., \& Siringi, D. O. (2020). Investigating electrocoagulation as an alternative treatment method for wastewater from Slaughterhouses in Kenya. Paper presented at the Proceedings of sustainable research and innovation conference.

[33] Muriuki, C., Kairigo, P., Home, P., Ngumba, E., Raude, J., Gachanja, A., \& Tuhkanen, T. (2020). Mass loading, distribution, and removal of antibiotics and antiretroviral drugs in selected wastewater treatment plants in Kenya. Science of The Total Environment, 743, 140655.

[34] Mwaka, S. N. (2019). Evaluation of constructed wetland and conventional wastewater treatment systems in selected Kenyan Tea Factories.

[35] Mwangi, B. (2016). Towards a National Policy on Wastewater Reuse In Kenya.

[36] Mwangi, V., Kollongei, J., \& Kipkorir, E. (2020). Effect of Irrigation with Waste Water on Soil Characteristics and Bean Yield: A Case Study of the University of Eldoret Farm. Africa Environmental Review Journal, 3(2), 179-189.

[37] Nadir, S., Tole, M., Dharani, N., \& Wafula, G. (2020). Effectiveness of a Wastewater Treatment Plant located at EPZ in reducing Pollutants Discharged into River Athi, Kenya.

[38] Nansubuga, I., Banadda, N., Verstraete, W., \& Rabaey, K. (2016). A review of sustainable sanitation systems in Africa. Reviews in environmental science and Bio/Technology, 15(3), 465-478.

[39] Ndunda, E. N. (2014). Wastewater reuse in urban and peri-urban irrigation: an economic assessment of improved wastewater treatment, low-risk adaptations and risk awareness in Nairobi, Kenya. The University of Pretoria.

[40] Ndunda, E. N., \& Mungatana, E. D. (2013). Evaluating the welfare effects of improved wastewater treatment using a discrete choice experiment. Journal of environmental management, 123, 49-57.

[41] Ngigi, A., \& Macharia, D. (2006). Kenya Education sector policy overview paper. Nairobi: IT Power East Africa.

[42] Nyakang'o, J., \& Van Bruggen, J. (1999). Combination of a well-functioning constructed wetland with a pleasing landscape design in Nairobi, Kenya. Water Science and Technology, 40(3), 249-256.

[43] Nzengy'a, D. M., \& Wishitemi, B. L. (2001). The performance of constructed wetlands for, wastewater treatment: a case study of Splash wetland in Nairobi Kenya. Hydrological processes, 15(17), 3239-3247.

[44] Odhiambo, J., Yusuf, A., \& Onyatta, J. (2016). Assessment of selected parameters for industrial effluents from some industrial sites in Nairobi, Kenya.

[45] Omosa, I. B., Wang, H., Cheng, S., \& Li, F. (2012). Sustainable tertiary wastewater treatment is required for water resources pollution control in Africa: ACS Publications.

[46] Opijah, F. J., Mukabana, J. R., \& Ng'ang'a, J. K. (2007). Rainfall distribution over the Nairobi area.

[47] Organization, W. H. (2008). Progress on drinking water and sanitation: World Health Organization.

[48] Pavithra, M., \& Hina, K. (2016). Characterization of certain physico-chemical parameters of textile wastewater. International journal of environmental sciences, $5(1), 39-41$.

[49] Ramin, E., Bestuzheva, K., Gargalo, C. L., Ramin, D., Schneider, C., Ramin, P., . . Gernaey, K. V. (2021). Incremental design of water symbiosis networks with prior knowledge: The case of an industrial park in Kenya. Science of The Total Environment, 751, 141706.

[50] Seow, T. W., Lim, C. K., Nor, M., Mubarak, M., Lam, C. Y., Yahya, A., \& Ibrahim, Z. (2016). Review on wastewater treatment technologies. International Journal of applied Environment science, 11(1), 111-126.

[51] Sewe, H. A. (2013). A study on the Efficiency of Dandora Domestic and Industrial Wastewater Treatment Plant in Nairobi.

[52] Shikuku, V. O., \& Achieng, G. O. (2017). Distribution and removal efficiency activated sludge at municipal wastewater. Research Journal of Chemical, 7(8), 1925.

[53] Song'oro, E., Nyerere, A., Magoma, G., \& Gunturu, R. (2019). Occurrence of Highly Resistant Microorganisms in Ruai Wastewater Treatment Plant and Dandora Dumpsite in Nairobi County, Kenya. Advances in Microbiology, 9(5), 479-494.

[54] Wakhungu, M. J. (2019). An ethnography of policy: water reuse policy in Kenya. Water Policy, 21(2), 436-448. 


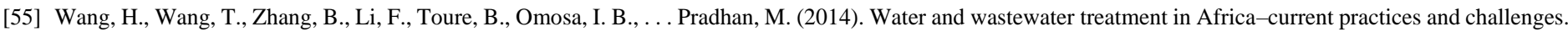
CLEAN-Soil, Air, Water, 42(8), 1029-1035.

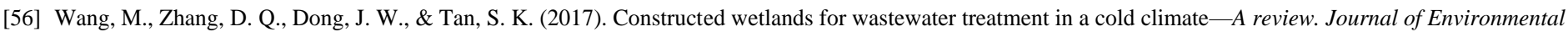
Sciences, 57, 293-311.

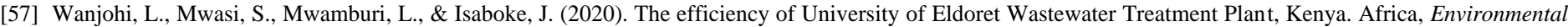
Review Journal, 3(2), 99-109.

[58] WWAP, U. (2017). Wastewater: the Untapped Resource, The United Nations World Water Development Report: UNESCO, Paris.

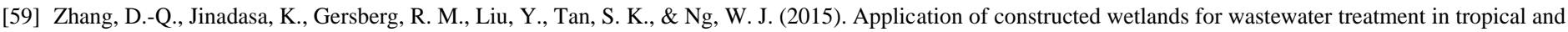
subtropical regions (2000-2013). Journal of Environmental Sciences, 30, 30-46.

\section{AUTHORS}

First Author -Flory Kilingo Mkangombe, BSC Bachelor of Education Science, currently pursuing a Master of Environmental Science and Engineering at Tongji University in Shanghai China. UNEP-TONGJI Institute of Environmental Sciences and Sustainable Development (IESD) Tongji University, College of Environmental Science and Engineering, Tongji University, Shanghai 200092, China. Email: florymkangombe@ gmail.com

Second Author - Zulu Bernard, BSC Bachelor of Education Science, currently pursuing a Master of Environmental Science and Engineering at Tongji University in Shanghai China. UNEP-TONGJI Institute of Environmental Sciences and Sustainable Development (IESD) Tongji University, College of Environmental Science and Engineering, Tongji University, Shanghai 200092, China. Email:

Third Author - Prof. Chen Hongbin, Biological wastewater treatment, industrial (petrochemical) wastewater recycling technology and application; State Key Laboratory of Pollution control and Resource Reuse, College of Environment Science and Engineering, Tongji University No 588 Miyun Rd. Shanghai, P.R. China,200092. Tel: 0086-21-65984569, Email: bhctxc@tongji.edu.cn

Correspondence Author - Prof. Chen Hongbin, , Email: bhctxc@tongji.edu.cn, contact number Tel: 0086-21-65984569. 